of Davis Straits and Iceland, the cod populations of Iceland being thought previously to be self-contained.

This year is the second International Polar Year, when polar hydrographical conditions will be specially investigated by all nations. It is hoped that intensive observations will be made of internal waves in the Southern Cattegat during a period of seven days in August. The English hydrographic programme includes an extension of the total current measurements which have been carried out at the Varne Lightship in the past.

The question as to whether the Limnological and the Plankton Committees should remain as separate entities was discussed, and it was decided to reconsider this at the next meeting.

Special scientific meetings on plankton and hydrology dealt with the conditions of plant life in the sea. Prof. Gran, as chairman of the Plankton Committee, reviewed recent work on the effects of phosphates and nitrates on the growth of plankton. From his ewn work he inclines to the belief that manganese and iron derived from coastal waters are necessary, in addition to phosphates and nitrates, for planktonic growth in Atlantic waters.
Dr. Henry Bigelow, of Woods Hole Oceanographical Institution, attended the meeting as a visitor and outlined plans for future work in the North Atlantic in which the North American Council on Fisheries Investigations might co-operate with the International Council. The Council expressed appreciation of the work to be carried out on the western side of the Atlantic, and declared that the moment is opportune to enter into close co-operation with both the Woods Hole Institution and the North American Council of Fisheries Investigations, and that this can best be achieved by close personal touch between the workers. The Council invite representatives of both bodies to take part regularly in its deliberations, in order to arrive at unity of plan and methods in the study of those fundamental problems which are similar or identical on both sides of the Atlantic.

The conclusions of the delegates are that the organisation is on a thoroughly sound footing; that its reputation in the scientific world has grown and continues to grow; that the welfare of the fishing industry demands the continuance of scientific investigations, and that the Council should be encouraged to continue its useful work.

\title{
Forestry in Trinidad and Tobago*
}

TWHE keynote of the Annual Report of the Forest Department of Trinidad and Tobago (Trinidad, May 1931) is to be found in the opening paragraph on "Forest Resources". The conservator, Mr. R. C. Marshall, is able to write: "As a result of a considerable amount of detailed field work during the last few years, we are now in a position, in regard to a considerable area of forest, to be able to substitute a clear picture of the stand of timber for the vague general idea with which, in the past, we have had to be content". Unfortunately, in far too large a proportion of the Empire forest departments this vague general idea of the forest resources still persists. The survey of the forests in Trinidad is being effected by the well-known method of running lines in carefully considered directions 100 chains apart and enumerating the trees on the lines, thus obtaining a one per cent enumeration; 6000 chains of lines were run in 1929 and 5600 in 1930.

From the enumeration surveys already made, it is now established that the Colony's 600,000 acres of forest contain a very large amount of wood. This is supported by the stock-taking effected on 1000 acres of mora (Dimorphandra mora) in Mayaro, and on 1000 acres of mixed forest in the Central Range Reserve, in which crappo (Carapa guianensis) and guatecare (Lecythis lavifolia) form the most plentiful of the useful species. Appendix D gives the data of the species found on these two areas and is of great interest. It has established the fact that the mora forest in its constitution is far more comparable with the pure forests of temperate regions, which provide the bulk of the timber of commerce. It is considered possible, therefore, that this type of forest gives possibilities of regulated commercial working or 'lumbering' in the Colony. These two types of forest are representative of a large proportion of the forests of the Colony. "Increased utilisation of our forest resources", writes the Conservator, "hinges mostly on getting together stocks of timber and seasoning them properly." In view of the fact that the Colony imported $£ 233,000$ of forest produce during the year,

* Trinidad and Tobago: Forest Department. Administration Report of the Conservator for the Year 1930. Pp. 22. (Trinidad : Government Printing Office, Port of Spain, 1931.) 18. this rightly forms one of the problems which is receiving the closest consideration.

The two most popular woods in the Colony are said to be cedar (Cedrus mexicana) and balata (Mimusops balata var. Cruegeri). The enumeration surveys have shown the very small proportion which these species bear to the total crop, and that the younger age classes are very deficient. It is with satisfaction that we read that working plans are being prepared, and that in the case of cedar they prescribe and control the yield. Other plans are in course of preparation, one for the control of the mangrove swamps close to Port of Spain, which are a very important source of fuel wood for the city.

The Report is replete with details of progress which will have a far-reaching effect on the prosperity of the Colony. Mention can only be made of interesting sylvicultural experiments and sowing and planting work; of investigations in connexion with forest soils in collaboration with Prof. Hardy, of the Soil Department of the Imperial College of Tropical Agriculture; and finally, in collaboration with the Trinidad Government Railway, a beginning has been made with wood preservation experiments in connexion with the treatment of mora sleepers. The administrators of the Colony are to be congratulated on the marked progress which their Forest Department has achieved in the past few years.

In Leaflet No. 4 of the Forest Department, Mr. R. C. Marshall deals with the "Forest Trees of Trinidad and Tobago, with Special Reference to their Timbers". The leaflet gives a reasonably complete list of the more prominent forest trees, stating the size to which various species grow, their relative abundance, and giving in a concise form some information as to the timber they produce. It is not, nor does it purpose to be, a complete list of all forest tree species. As noted above, there are 600,000 acres of forest in the Colony. With the exception of the mora forests, which are of special interest through the gregarious habit of mora and the large stocking per acre, practically all the remainder is of a very mixed type such as is common in tropical rain forest, to which category most of the forests belong. Two tabular statements are attached which show the trees by one foot girth 
classes, enumerated on 1000 acres of each type; these tables give some idea of the large number of species which constitute the mixed type of rain forest as compared with the mora forest.

In Leaflet No. 3 of the same Department a note has been drawn up by Mr. R. L. Brooks, deputy conservator of forests, on "An Experiment on Air Seasoning of Native Timbers". Experiments with some of the native woods have been carried out under the supervision of Mr. Brooks, and so far as they have gone apparently justify the hopes of ultimate success. The imports of lumber into the Colony are high, and Mr. Brooks is definitely of opinion that they could be considerably reduced if stocks of seasoned local timber were made available.

\section{Electrical Heresies}

IN Stanford University Publications, University 1 Series, Mathematics and Astronomy, vol. 2, No. 1, Fernando Sanford, emeritus professor of physics, discusses terrestrial electricity and related topics. The volume, of 208 pages, is well produced and interestingly written; but it would form a very unsafe guide to knowledge. The author propounds views that he recognises as being very heretical, and bound to meet with a hostile reception; but it would be mistaken to be disarmed by his candour in this respect. His cardinal heresy is that "absolute electrical neutrality is unknown upon the earth, and could not be recognised if it were observed" (p. 71).

Prof. Sanford supposes that the ratio of the numbers of protons and electrons may be variable within wide limits upon different planets. In particular, he believes that the sun and earth possess large negative charges-large enough, in the case of the earth, to explain the magnetic field as a result of the daily rotation of the charge. $\mathrm{He}_{\theta}$ is aware of the familiar argument-simplest in the case of the sun-that the charge would be expelled by mutual repulsion and the outflow of electrons from the ionised solar atmosphere; but he denies that the electric charge upon a conductor exerts an outward pull upon the atoms of the conductor (though the experiment of an expanding charged soap-bubble would seem to indicate that they do), and that free electrons are held to the sun by gravitation alone. $\mathrm{He}$ asserts that electrons are apparently held to conductors by the pressure of the surrounding ether, which can sustain very great charges upon bodies. His positive arguments for the existence of a large solar charge are based on the supposed necessity for considerable charge-densities to explain the magnetism of sunspots, and also of the sun as a whole; also upon the electron gas theory of the solar corona, and on the supposed electrical repulsion of comets' tails-all of them being highly debatable matters, certainly not yet explained according to the generally accepted laws, but very unsuitable as foundations for a striking break-away from these laws.

Further, Prof. Sanford suggests that electrical repulsions between the sun and planets may produce planetary perturbations (particularly for Mercury), and that the daily variation of the charge induced upon the earth by the sun can be detected. His interpretation of his observations on this point is unlikely to gain favour, but the observations themselves might usefully be checked by other observers. Later chapters of the book deal with the electrostatic field of the earth, earth-currents and magnetic varia. tions, magnetic storms and solar activity, magnetic and electric influence of the moon, and barometric pressure and the earth's electric charge; to the reviewer they appear to abound with unlikely hypotheses.

\section{International Congress of Prehistoric and Protohistoric Sciences}

A PRELIMINARY outline of the arrangements A for the First International Congress of Prehistoric and Protohistoric Sciences, which is to be held in London, has been issued, and it is announced that in order to meet the convenience of foreign delegates the date of meeting will be Aug. 1-6, instead of July 25-30, originally arranged. The first meeting will be held on the afternoon of Aug. 1, and formal meetings will be continued during the week. The following week will be devoted to excursions to places of archæological interest. The Congress will meet under the presidency of Sir Charles Peers, Mr. R. Holland-Martin will act as treasurer, and the general secretaries are Prof. A. W. Brøgger and Prof. J. L. Myres. These appointments were made at the first meeting of the permanent council held in Paris in October last.

In accordance with a further decision of the permanent council, the work of the Congress will be divided into sections, arranged according to practical requirements rather than on strictly scientific lines. A classification of subject matter has been made for the first Congress, on the understanding that future division will be considered at the Congress. The following is the list of sections, with the names of the British archæologists who have been invited to act as presidents: Human Palæontology, the Origin and Evolution of Prehistoric Man (Sir Arthur Smith Woodward); Palæolithic and Mesolithic Periods (Mr. Reginald Smith); The Neolithic, Bronze, and Iron Ages in the Ancient World (Prof. H. J.
Fleure, Prof. J. L. Myres, Mr. Sydney Smith); The Neolithic, Bronze, and Iron Ages outside the Ancient World (Dr. H. S. Harrison and Prof. C. G. Seligman); The Passage from Prehistory to History (Mr. E. T. Leeds).

A number of questions has been placed on the agenda, although it is understood that communications on other matters may be offered, provided they come within the limits imposed by the statutes. Among the subjects specifically mentioned are the present state of our knowledge of fossil man, discoveries of human industries in the drift and the loess, the mesolithic question, the megalithic monuments, the problems of the copper and early bronze ages in western Europe, the origin of Mediterranean civilisations, the oriental basis of Egean chronology, Mediterranean contacts of the west European cultures of late bronze age and Hallstadt types, the Continental sources of racial and industrial types among the Anglo-Saxons, the origin and chronology of the Viking movements. Communications must be sent to the Secretary of the British Organising Committee, Society of Antiquaries, Burlington House, Piccadilly, London, W.1, before May 1, 1932.

Excursions have been arranged, to follow the Congress. They begin on Aug. 6, when those joining will be divided into two parties, of which one will stay at Oxford until Aug. 9, visiting the Rollright Stones, Wayland's Smithy, Uffington, etc., as well as the Ashmolean and Pitt-Rivers Museums. The second party will stay at Cambridge until Aug. 9, 